\title{
Pengaruh proporsi penambahan daun katuk (Sauropus androgynus L. Merr.) terhadap sifat fisiko kimia selai lembaran apel
}

\author{
Effect of additional katuk leaf (Sauropus androgynus L. Merr.) on physic chemical \\ properties in apple sheet jam \\ Eva Nirwana Anwar ${ }^{1{ }^{*}}$, Rekna Wahyuni ${ }^{1)}$ \\ ${ }^{1}$ Program Studi Ilmu dan Teknologi Pangan, Universitas Yudharta Pasuruan, Indonesia \\ *Email: eva95nirwana@gmail.com
}

Dikirim: 12/03/2020; ditinjau: 13/03/2020; disetujui: 28/30/2020

\begin{abstract}
Anna apple jam is defined as an apple jam that is modified into apple jam in sheet form (sheet jam). Apple anna makes it possible as a raw material for making jam sheets because it has a high pectin, which is $9-15 \%$ and has acidity in accordance with the requirements, which is 3.46. Katuk plant (Sauropus androgynus L. Merr.) has long been known by the people in Indonesia as a vegetable plant with a high nutritional content. Flavonoids contained in katuk leaves (Sauropus androgunus L. Merr) have the ability as a powerful antioxidant. The experimental design used was a randomized block design (RBD) consisting of 1 factor with 5 treatments: K1 (Addition of 0\% katuk leaf pulp, 100\% apple pulp), K2 (Addition of katuk leaf pulp 5\%, 95\% apple pulp ), K3 (Addition of katuk leaf pulp 10\%, pulp of apples 90\%), K4 (Addition of katuk leaf pulp $15 \%, 85 \%$ apple pulp) and K5 (Addition of katuk leaf pulp 20\%, apple pulp 80\%). Data obtained after the treatment of the organoleptic test (flavor, taste, texture and color) on each variable was entered in the table to be analyzed by Friedman Test. Where as in the treatment of physicochemical tests (water content, antioxidants, texture and color) were analyzed by $F$ test and if there were differences were analyzed by 5\% LSD test. The best treatment based on effectiveness index was K2 (addition of katuk leaf pulp 5\%, apple pulp 95\%) with physicochemical parameter values namely water content (45.69\%), antioxidants $(96.67 \mathrm{mg} / \mathrm{ml})$, texture (1.17), color $b+(7.47)$ and organoleptic parameter values are taste (4.44), flavor (4), color (4.28), texture (3.76).
\end{abstract}

Keywords: apple, jam, Sauropus androgynus L. Merr.

\begin{abstract}
ABSTRAK
Selai lembaran apel anna didefinisikan sebagai selai apel yang dimodifikasi menjadi selai apel dalam bentuk lembaran (selai lembaran). Apel anna memungkinkan sebagai bahan baku pembuatan selai lembaran karena memiliki pektin tinggi, yaitu 9-15\% dan memiliki keasaman yang sesuai dengan persyaratan, yakni 3,46. Tanaman katuk (Sauropus androgynus L. Merr.) telah lama dikenal masyarakat di Indonesia sebagai tanaman sayuran dengan kandungan gizi yang cukup tinggi. Flavonoid yang terkandung dalam daun katuk (Sauropus androgunus (L) Merr) memiliki kemampuan sebagai antioksidan yang kuat. Rancangan percobaan yang digunakan adalah Rancangan acak kelompok (RAK) yang terdiri dari 1 faktor dengan 5 perlakuan yaitu K1 (Penambahan bubur daun katuk $0 \%$, bubur buah apel $100 \%$ ), K2 (Penambahan bubur daun katuk 5 $\%$, bubur buah apel $95 \%$ ), K3 (Penambahan bubur daun katuk $10 \%$, bubur buah apel $90 \%$ ), K4 (Penambahan bubur daun katuk $15 \%$, bubur buah apel $85 \%$ ) dan K5 (Penambahan bubur daun katuk $20 \%$, bubur buah apel $80 \%$ ). Data yang didapatkan
\end{abstract}


setelah perlakuan penelitian uji organoleptik (aroma, rasa, tekstur dan warna) pada masing-masing variabel dimasukkan dalam tabel untuk dianalisa Uji Friedman. Sedangkan pada perlakuan penelitian uji fisikokimia (kadar air, antioksidan, tekstur dan warna) dianalisa dengan uji $\mathrm{F}$ dan jika terdapat perbedaan dianalisa dengan Uji BNt 5\%. Perlakuan terbaik berdasarkan indeks efektivitas yaitu K2 (Penambahan bubur daun katuk $5 \%$, bubur buah apel $95 \%$ ) dengan nilai parameter fisikokimia yaitu kadar air $(45,69 \%)$, antioksidan $(96,67 \mathrm{mg} / \mathrm{ml})$, tekstur $(1,17)$, warna $\mathrm{b}+(7,47)$ dan nilai parameter organoleptik yaitu rasa $(4,44)$, aroma $(4)$, warna $(4,28)$, tekstur $(3,76)$.

Kata kunci : apel, Sauropus androgynus L. Merr., selai

\section{PENDAHULUAN}

Selai termasuk produk olahan pangan yang berasal dari buah-buahan (Basu dan Shivhare, 2010; del Castillo et al., 2019). Pada saat ini, permintaan selai meningkat karena sarapan menggunakan roti telah menjadi kebiasaan masyarakat (Mathebula et al., 2017). Selai yang beredar di pasar baru berupa selai oles kemasan dengan cara penyajian yang kurang praktis. Oleh karena itu, pembuatan selai lembaran merupakan modifikasi selai oles menjadi lembaran kompak, plastis, dan tidak lengket (Putri et al., 2013).

Apel Anna mempunyai aroma yang kuat dengan rasa yang sangat asam karena kandungan asam dalam apel ini sangat tinggi dibanding kedua apel lokal lainnya yaitu apel varietas manalagi dan apel varietas rome beauty (Feng et al., 2014; Khurniyati, 2014; Violeta et al., 2010). Apel ini berpigmen merah tua dengan ukuran yang bervariasi. Rasa apel ini sangat renyah, lembut, dan kandungan airnya banyak (Oktaviananta, 2018). Apel anna memungkinkan sebagai bahan baku pembuatan selai lembaran karena memiliki pektin tinggi, yaitu $9-15 \%$ dan memiliki keasaman yang sesuai dengan persyaratan, yakni 3,46 (Iswara, 2017). Daun katuk memiliki rasa alami yang kurang diminati oleh konsumen, oleh karena itu pengolahan daun katuk diperlukan untuk menghasilkan variasi pengolahan makanan yang lebih beragam dan lebih disukai (Lumbangaol et al., 2016).
Tanaman katuk (Sauropus androgunus (L) Merr) mempunyai banyak manfaat dalam kehidupan sehari-hari (Eng Khoo et al., 2015; U. Santoso et al., 2010; Urip Santoso et al., 2013). Hasil penelitian Kelompok Kerja Nasional Tumbuhan Obat Indonesia menunjukkan bahwa tanaman katuk mengandung beberapa senyawa kimia, antara lain alkaloid papaverin, protein, lemak, vitamin, mineral, saponin, flavonid dan tanin (Selvi dan Bhaskar, 2012; Wei et al., 2011). Flavonoid yang terkandung dalam daun katuk (Sauropus androgunus (L) Merr) memiliki kemampuan sebagai antioksidan yang kuat. Beberapa senyawa kimia yang terdapat dalam tanaman katuk diketahui berkhasiat obat (Zuhra et al., 2008). Katuk merupakan satu-satunya tanaman lokal yang memiliki kandungan klorofil tertinggi. Kandungan antioksidannya juga besar, dan dapat dimanfaatkan untuk mencegah berbagai radikal bebas yang mempercepat penuaan (Ariesta, 2016).

Berdasarkan uraian tersebut di atas maka perlu dilakukan penelitian yang difokuskan pada pengaruh proporsi penambahan daun katuk (Sauropus androgynus L. Merr.) terhadap sifat fisiko kimia selai lembaran apel.

\section{METODE PELAKSANAAN}

Penelitian ini menggunakan rancangan percobaan yang digunakan adalah Rancangan acak kelompok (RAK) yang terdiri dari 1 faktor yaitu penambahan daun katuk dengan 5 kali perlakuan dan 3 kali ulangan. 
Tabel 1. Desain eksperimen

\begin{tabular}{cccc}
\hline \multirow{2}{*}{ Perlakuan } & \multicolumn{3}{c}{ Ulangan } \\
\cline { 2 - 4 } & I & II & III \\
\hline K1 & $\mathrm{U} 1$ & $\mathrm{U} 2$ & $\mathrm{U} 3$ \\
K2 & $\mathrm{U} 1$ & $\mathrm{U} 2$ & $\mathrm{U} 3$ \\
K3 & $\mathrm{U} 1$ & $\mathrm{U} 2$ & $\mathrm{U} 3$ \\
K4 & $\mathrm{U} 1$ & $\mathrm{U} 2$ & $\mathrm{U} 3$ \\
K5 & $\mathrm{U} 1$ & $\mathrm{U} 2$ & $\mathrm{U} 3$ \\
\hline
\end{tabular}

Keterangan

$\mathrm{K} 1=$ Penambahan bubur daun katuk 0\%, bubur buah apel $100 \%$

$\mathrm{K} 2=$ Penambahan bubur daun katuk $5 \%$, bubur buah apel $95 \%$

$\mathrm{K} 3=$ Penambahan bubur daun katuk $10 \%$, bubur buah apel $90 \%$

$\mathrm{K} 4=$ Penambahan bubur daun katuk $15 \%$, bubur buah apel $85 \%$

K5 $=$ Penambahan bubur daun katuk $20 \%$, bubur buah apel $80 \%$

\section{Bahan}

Bahan yang digunakan dalam penelitian adalah apel anna (Pasar Lawang), daun katuk (Jalan sumber suko no 276 RT 03 RW 01 Lawang - Malang), air, asam sitrat (cap gajah), agar-agar tepung (merk swallow) dan HPMC (Sakhakimia, Malang). Bahan yang digunakan untuk analisa laboratorium didapatkan di laboratorium terkait.

\section{Alat}

Alat yang digunakan dalam penelitian ini adalah blender (Philips), timbangan, kompor (Quantum). Alat untuk analisis antara lain wadah porselin, hotplate, tanur, cawan, labu ukur, spektofotometri, dan glass ware phyrex.

\section{Prosedur pengolahan selai lembaran}

Buah apel anna disortasi dan dicuci untuk membersihkan apel dari kotoran yang terikut. Buah apel kemudian dilakukan proses pengupasan untuk menghilangkan kulit dan biji. Daging buah apel kemudian dipotong dan direndam asam sitrat $2 \%$ selama 15 menit. Daging buah apel ditimbang lalu kemudian diblansir uap pada suhu $100^{\circ} \mathrm{C}$ selama 5 menit untuk menginaktivasikan enzim dalam bahan. Daging buah apel yang telah diblansir kemudian dihancurkan dengan air mineral dengan perbandingan daging buah dan air mineral 2:1.

Daun katuk disortasi dan dicuci untuk membersihkan daun dari kotoran yang terikut. Daun katuk kemudian dilakukan proses blansir $80^{\circ} \mathrm{C}$ untuk mengurangi rasa langu khas daun katuk. Daun katuk ditimbang lalu kemudian dihancurkan dengan air mineral dengan perbandingan daun katuk dan air mineral 1:1.

Bubur daun katuk dan bubur buah apel ditimbang dengan masing-masing perlakuan bubur daun katuk : K1 (Penambahan bubur daun katuk $0 \%$, bubur buah apel $100 \%$ ), K2 (Penambahan bubur daun katuk $5 \%$,

bubur buah apel $95 \%$ ), K3 (Penambahan bubur daun katuk $10 \%$, bubur buah apel $90 \%$ ), K4 (Penambahan bubur daun katuk $15 \%$, bubur buah apel $85 \%$ ) dan K5 (Penambahan bubur daun katuk $20 \%$, bubur buah apel $80 \%$ ). Bubur buah apel dipanaskan selama 5 menit, ditambahkan gula $55 \%$, agar $1 \%$ dan HPMC $0,6 \%$ (b/b bubur buah apel dan daun katuk) kemudian dipanaskan selama 10 menit, tambahkan bubur daun katuk panaskan selama \pm 1 menit untuk menjaga warna. Selai apel yang sudah jadi kemudian dikemas dengan plastik OPP (35 gram; $p=11 \mathrm{~cm}, 1=11 \mathrm{~cm})$.

\section{Analisa data}

Pengumpulan data dilakukan dengan observasi terhadap sifat organoleptik selai lembaran kepada 15 panelis terlatih dan 25 panelis semi terlatih. Sifat organoleptik selai lembaran meliputi warna, aroma, rasa, dan tekstur. Analisis data uji organoleptik menggunakan Uji Friedman. Parameter fisik kimia yang diamati pada produk lembaran adalah yang diamati pada selai lembaran adalah aktivitas antioksidan (DPPH IC50), kadar air (AOAC, 2005), warna (Colour Reader), tekstur (Texture Analyzer EZ - SX). 
penelitian uji fisikokimia dianalisa dengan uji $\mathrm{F}$ dan jika terdapat perbedaan dianalisa dengan Uji Tuckey. Perlakuan terbaik dianalisa menggunakan metode indeks efektifitas deGarmo et al., (1984) yang dimodifikasi oleh Susini (2003).

\section{HASIL DAN PEMBAHASAN}

\section{Uji fisiko kimia}

\section{Analisis kadar antioksidan DPPH IC50}

Berdasarkan

hasil

penelitian didapatkan rata-rata kadar antioksidan antara $81,22 \mathrm{mg} / \mathrm{ml}$ - 98,68 mg/ml. Data hasil pengujian antioksidan dapat dilihat pada Tabel 2. Semakin kecil nilai IC50, maka semakin tinggi aktivitas antioksidan yang dimiliki (Zuhria et al., 2017). Perlakuan penambahan proporsi daun katuk pada selai mempengaruhi kandungan antioksidan pada selai, hal ini dapat dilihat pada tabel semakin banyak bubur daun katuk yang di tambahkan maka semakin tinggi kandungan antioksidan.

Tabel 2. Rata-rata antioksidan (mg/ml)

\begin{tabular}{lc}
\hline \multicolumn{1}{c}{ Perlakuan } & $\begin{array}{c}\text { Antioksidan } \\
(\mathbf{m g} / \mathbf{m l})\end{array}$ \\
\hline K1 (Penambahan bubur daun katuk 0 \%, bubur buah apel 100\%) & $98,68 \mathrm{a}$ \\
K2 (Penambahan bubur daun katuk 5\%, bubur buah apel 95 \%) & $96,67 \mathrm{~b}$ \\
K3 (Penambahan bubur daun katuk 10\%, bubur buah apel 90\%) & $95,04 \mathrm{c}$ \\
K4 (Penambahan bubur daun katuk 15 \%, bubur buah apel 85\%) & $87,76 \mathrm{~d}$ \\
K5 (Penambahan bubur daun katuk 20\%, bubur buah apel 80 \%) & $81,22 \mathrm{e}$ \\
\hline
\end{tabular}

Keterangan: Nilai rata-rata yang diikuti oleh huruf yang sama tidak berpengaruh nyata menurut uji tuckey

Kandungan flavonoid pada ekstrak daun katuk diidentifikasi berpotensi sebagai sumber bahan makanan yang kaya flavonoid dan antioksidan (Andini, 2014). Tanaman katuk (Sauropus androgunus (L) Merr) mengandung flavonoid yang memiliki kemampuan antioksidan yang kuat. Secara spesifik suatu senyawa dikatakan sebagai antioksidan sangat kuat jika nilai IC50 kurang dari 50 ppm, kuat untuk IC50 bernilai 50-100 ppm, sedang jika bernilai 100-150 ppm, dan lemah jika nilai IC50 bernilai 151200 ppm (Zuhra et al., 2008). Selai lembaran apel dengan perlakuan proporsi penambahan daun katuk megandung antioksidan dapat dikategorikan sebagai antioksidan kuat bernilai $50-100 \mathrm{ppm}$.

\section{Analisis kadar air}

Berdasarkan analisa kadar air yang dilakukan pada selai apel dengan perlakuan penambahan proporsi daun katuk didapatkan rata-rata rata-rata kadar air 44,56\% sampai $47,84 \%$. Data hasil pengujian kadar air dapat dilihat pada Tabel 3. Perlakuan penambahan proporsi daun katuk pada selai mempengaruhi kadar air pada selai, hal ini dapat dilihat pada tabel semakin banyak bubur daun katuk yang di tambahkan maka semakin tinggi kadar air.

Tabel 3. Rata-rata kadar air (\%)

\begin{tabular}{cc}
\hline Perlakuan & Kadar Air (\%) \\
\hline K1 (Penambahan bubur daun katuk 0 \%, bubur buah apel 100 \%) & $44,56 \mathrm{a}$ \\
K2 (Penambahan bubur daun katuk 5\%, bubur buah apel 95\%) & $45,69 \mathrm{~b}$ \\
K3 (Penambahan bubur daun katuk 10 \%, bubur buah apel 90\%) & $46,08 \mathrm{~b}$ \\
K4 (Penambahan bubur daun katuk 15 \%, bubur buah apel 85 \%) & $46,33 \mathrm{~b}$ \\
K5 (Penambahan bubur daun katuk 20\%, bubur buah apel 80\%) & $47,84 \mathrm{c}$ \\
\hline
\end{tabular}

Keterangan: Nilai rata-rata yang diikuti oleh huruf yang sama tidak berpengaruh nyata menurut uji tuckey

Semakin lama waktu pemasakan kadar air akan menurun, menyebabkan penguapan air lebih banyak sehingga kadar air dalam bahan semakin kecil. Tekanan uap air pada bahan pada umumnya lebih besar dari tekanan uap air di udara sehingga terjadi 
perpindahan massa air dari bahan ke udara (Nilasari et al., 2017). Pada penelitian ini pemasakan bubur apel anna lebih lama dibandingkan pemasakan bubur daun katuk yang mengakibatkan kadar air pada bubur buah apel lebih tinggi dibandingkan bubur daun katuk.

\section{Analisis warna}

Pengujian warna dilakukan dengan menggunakan instrument Color Reader. Hasil pengukuran warna terbagi menjadi tiga parameter yaitu L (Lightness), a (greenness) dan $\mathrm{b}^{+}$(yellowness). Hasil pengujian warna selai lembaran apel dapat dilihat pada tabel 4 .

Tabel 4. Rata-rata kadar air (\%)

\begin{tabular}{lccc}
\hline Perlakuan & $\mathrm{L}$ & $\mathrm{a}^{-}$ & $\mathrm{b}^{+}$ \\
\hline K1 (Penambahan bubur daun katuk 0 \%, bubur buah apel 100\%) & $32 \mathrm{a}$ & $7,22 \mathrm{a}$ & $12,3 \mathrm{a}$ \\
K2 (Penambahan bubur daun katuk 5 \%, bubur buah apel 95 \%) & $28,8 \mathrm{~b}$ & $7,4 \mathrm{~b}$ & $12,8 \mathrm{a}$ \\
K3 (Penambahan bubur daun katuk 10 \%, bubur buah apel 90\%) & $28,4 \mathrm{~b}$ & $8,31 \mathrm{c}$ & $14,6 \mathrm{~b}$ \\
K4 (Penambahan bubur daun katuk 15 \%, bubur buah apel 85 \%) & $27,3 \mathrm{c}$ & $8,53 \mathrm{~d}$ & $14,1 \mathrm{~b}$ \\
K5 (Penambahan bubur daun katuk 20 \%, bubur buah apel 80 \%) & $24,2 \mathrm{~d}$ & $8,85 \mathrm{e}$ & $11,0 \mathrm{c}$ \\
\hline
\end{tabular}

Keterangan: nilai rata-rata yang diikuti oleh huruf yang sama tidak berpengaruh nyata menurut uji tuckey

Hasil pengujian warna selai lembaran apel menunjukkan warna hijau-kekuningan dengan nilai L kisaran antara $(24,2-32)$, nilai $\mathrm{a}^{-}(7,22-8,85)$ dan nilai $\mathrm{b}^{+}(11-14,6)$. Daun katuk (Sauropus androgynus Merr.) digunakan sebagai pewarna alami yang dapat memberi warna hijau tanpa menimbulkan residu. Pemanfaatannya dengan diekstrak atau ditumbuk dengan menambahkan air, kemudian filtratnya digunakan untuk pewarna hijau pangan (Hardjanti, 2008) Semakin tinggi proporsi substitusi tepung daun katuk, maka semakin gelap pada warna hijau tua, serta semakin tinggi kandungan klorofil yang dikandungnya (Satyaningtyas dan Estiasih, 2013). Pada penelitian ini tingkat kehijauan selai lembaran mengalami kenaikan seiring dengan semakin banyaknya proporsi daun katuk yang ditambahkan karena penambahan bubur daun katuk yang mengandung klorofill mempengaruhi kenaikan tingkat kehijauan selai dan nilai lightness selai lembaran semakin turun.

\section{Analisis tekstur}

Berdasarkan analisa tekstur yang dilakukan pada selai apel dengan perlakuan penambahan proporsi daun katuk didapatkan rata-rata tekstur $0,5 \mathrm{~N}$ sampai $1,5 \mathrm{~N}$. Hasil pengujian tekstur selai lembaran apel dapat dilihat pada Tabel 5.

Tabel 5. Rata-rata tekstur (N)

\begin{tabular}{lc}
\hline Perlakuan & Tekstur (N) \\
\hline K1 (Penambahan bubur daun katuk 0 \%, bubur buah apel 100 \%) & $1,5 \mathrm{a}$ \\
K2 (Penambahan bubur daun katuk 5\%, bubur buah apel 95 \%) & $1,2 \mathrm{~b}$ \\
K3 (Penambahan bubur daun katuk 10 \%, bubur buah apel 90\%) & $1,0 \mathrm{c}$ \\
K4 (Penambahan bubur daun katuk 15 \%, bubur buah apel 85 \%) & $0,7 \mathrm{~d}$ \\
K5 (Penambahan bubur daun katuk 20\%, bubur buah apel 80\%) & $0,5 \mathrm{e}$ \\
\hline
\end{tabular}

Keterangan: Nilai rata-rata yang diikuti oleh huruf yang sama tidak berpengaruh nyata menurut uji tuckey

Kadar air dapat mempengaruhi penampakan dan tekstur suatu bahan pangan. Sehingga selai yang memiliki kadar air yang lebih rendah cenderung memiliki tekstur yang lebih keras dibandingkan selai yang memiliki kadar air lebih tinggi (Herianto et $a l ., 2015)$. Selai pada penelitian ini memiliki kadar air yang tinggi karena menggunakan puree apel dan daun katuk yang pada penghancurannya ditambah dengan air sehingga memiliki kadar air yang cukup tinggi. Oleh sebab itu kadar air selai yang tinggi tersebut menyebabkan tekstur yang lembut. 


\section{Uji organoleptik}

Pengujian organoleptik dilakukan berdasarkan kesukaan terhadap selai lembaran apel yang meliputi warna, rasa, aroma dan tekstur. Panelis yang digunakan panelis tidak terlatih. Skala kesukaan yang digunakan mulai dari skor 1 (sangat tidak suka) sampai 5 (sangat suka).

\section{Uji organoleptik aroma}

Hasil uji organoleptik menunjukkan bahwa rata-rata ranking kesukaan terhadap aroma dari perlakuan antara persentase perbedaan proporsi daun katuk berkisar antara 2,96 sampai 4,0. Hasil pengujian organoleptik terhadap aroma selai lembaran apel dapat dilihat pada Gambar 1.

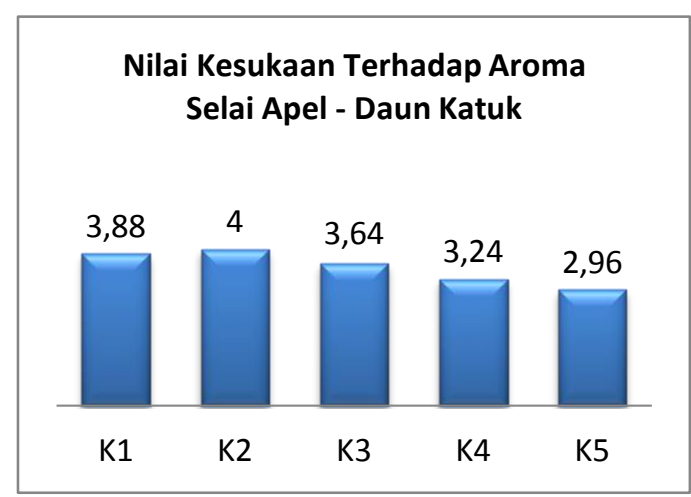

Gambar 1. Nilai kesukaan terhadap aroma.

Dari pengamatan di atas dapat disimpulkan bahwa semakin tinggi konsentrasi proporsi bubur daun katuk yang digunakan, maka aroma yang yang dihasilkan pada produk selai akan semakin langu khas katuk. Perlakuan blansing yang sama menyebabkan penguapan senyawa volatil pada tanaman katuk sehingga perlakuan penambahan daun katuk tersebut menghasilkan skor aroma yang tidak berbeda nyata. Menurut Rahmawati (2016), menyatakan bahwa proses blansing baik itu blansing air mendidih dan blansing uap air menurunkan aroma dari tepung katuk karena pada saat blansing senyawa volatil pada katuk sebagian menguap.

\section{Uji organoleptik warna}

Hasil uji panelis menyajikan bahwa rata-rata ranking kesukaan panelis terhadap warna dari perlakuan konsentrasi proporsi penambahan bubur daun katuk berkisar antara 2,52 sampai 4,28. Rata-rata tingkat kesukaan panelis terhadap warna selai apel daun katuk dapat dilihat pada gambar 2. di bawah ini.

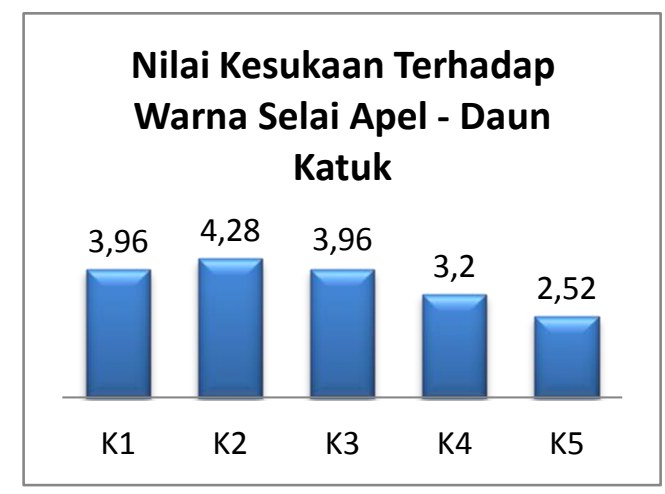

Gambar 2. Nilai kesukaan terhadap warna.

Dari hasil pengamatan di atas dapat disimpulkan bahwa semakin tinggi proporsi penambahan daun katuk akan mempengaruhi tingkat kesukaan pada warna selai apel-daun katuk. Selai apel perlakuan K2 memiliki nilai tertinggi sehingga yang paling disukai oleh panelis, dikarenakan adanya sedikit penambahan warna hijau dan sedikit kuning pada selai apel yang berwarna kuning pucat. pada perlakuan K5 mendapat nilai terjelek karena pada selai berwarna hijau pekat tertutup butiran daun dari puree atau bubur daun katuk.

\section{Uji organoleptik tekstur}

Hasil uji organoleptik menunjukkan bahwa rata-rata ranking kesukaan panelis terhadap tekstur dari perlakuan antara persentase perbedaan penambahan proporsi berkisar antara 2,96 sampai 4. Rata-rata tingkat kesukaan panelis terhadap tekstur selai apel - daun katuk dapat dilihat pada gambar 3. di bawah ini.

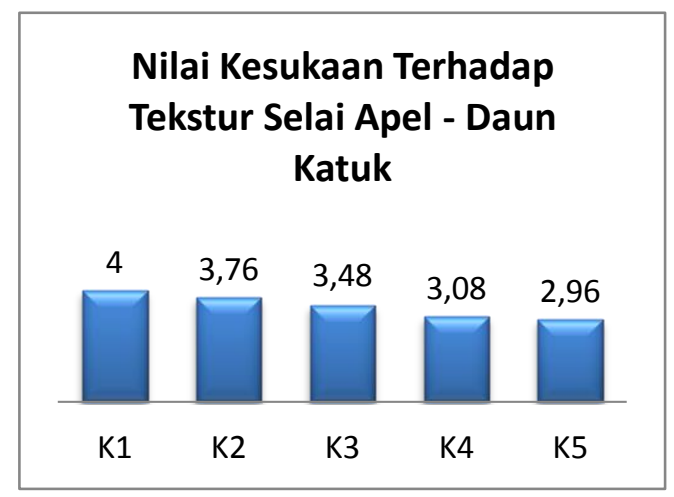

Gambar 3. Nilai kesukaan terhadap tekstur.

Dari hasil pengamatan di atas dapat 
disimpulkan bahwa semakin tinggi proporsi penambahan daun katuk akan mempengaruhi tingkat kesukaan pada tekstur selai apel-daun katuk. Semakin bertambahnya proporsi bubur daun kata maka semakin rendah nilai kesukaan selai lembaran apel terhadap tekstur.

Kadar air dapat mempengaruhi penampakan dan tekstur suatu bahan pangan. Sehingga selai yang memiliki kadar air yang lebih rendah cenderung memiliki tekstur yang lebih keras dibandingkan selai yang memiliki kadar air lebih tinggi (Herianto et al., 2015). Dari hasil uji di atas dapat disimpulkan bahwa semakin tinggi konsentrasi proporsi penambahan bubur daun katuk mempengaruhi nilai kesukaan panelis terhadap tekstur. Semakin bertambahnya konsentrasi proporsi bubur katuk berpengaruh terhadap semakin lunaknya selai lembaran apel-daun katuk.

\section{Uji organoleptik rasa}

Hasil uji organoleptik menyajikan bahwa rata-rata ranking kesukaan panelis terhadap rasa dari perlakuan antara persentase perbedaan penambahan proporsi bubur daun katuk berkisar antara 2,96 sampai 4,44. Rata-rata tingkat kesukaan panelis terhadap rasa selai apel - daun katuk dapat dilihat pada gambar 4 .

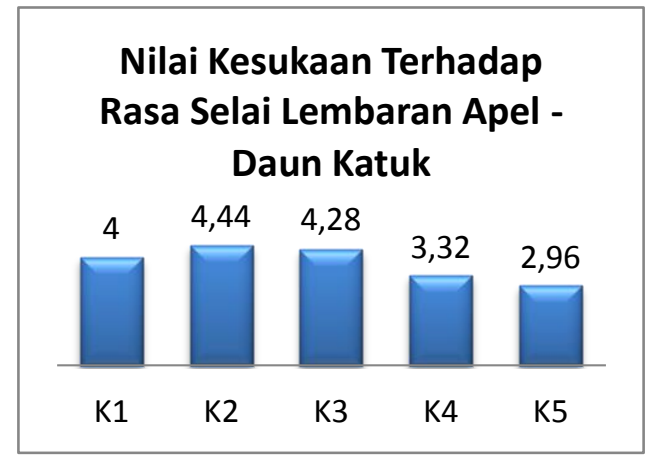

Gambar 4. Nilai kesukaan terhadap rasa

Dari pengamatan di atas dapat disimpulkan bahwa semakin tinggi konsentrasi proporsi bubur daun katuk yang digunakan, maka rasa yang yang dihasilkan pada produk selai akan semakin langu khas katuk. Dan sedikit penambahan daun katuk dapat mengurangi rasa khas apel anna yang lebih masam.

\section{KESIMPULAN}

Perlakuan terbaik yaitu perlakuan K2 (Penambahan bubur daun katuk $5 \%$, bubur buah apel $95 \%$ ) dengan karakteristik sebagai berikut: rata-rata kadar air 45,69\%; kadar antioksidan IC50 96,67 mg/ml; tekstur 1,2 N; warna $7,47 \quad\left(\mathrm{a}^{-}\right)$; serta rata-rata tingkat kesukaan panelis terhadap rasa 4,4 (suka); warna 4,28 (suka); aroma 4 (suka) dan tekstur 3,76 (cukup).

\section{SARAN}

Berdasarkan hasil penelitian pembuatan selai lembaran apel dengan perbedaan perlakuan penambahan proporsi daun katuk, saran yang dapat diberikan di antaranya :

1. Perlu dikaji lebih lanjut dengan perbandingan perlakuan terhadap daun yaitu sari daun katuk dan bubuk daun katuk sehingga perbedaan mutu dapat diketahui dengan berbagai perlakuan pendahuluan.

2. Perlu dikaji penelitian lebih lanjut tentang masa simpan produk sehingga penurunan mutu pada waktu penyimpanan serta masa kadaluarsanya bisa ditentukan dan produk selai lembaran Apel dapat dikonsumsi konsumen dengan aman.

\section{UCAPAN TERIMA KASIH}

Pada kesempatan ini penulis mengucapkan puji syukur kehadirat Allah SWT dan mengucapkan terima kasih kepada Bapak Teguh Sarwo Aji, SP., MMA selaku Dekan Fakultas Pertanian Universitas Yudharta dan Ibu Ir. Rekna Wahyuni, MP. selaku dosen pembimbing tugas akhir dan kaprodi Ilmu dan Teknologi Pangan sehingga dapat menyelesaikan penelitian ini.

\section{DAFTAR PUSTAKA}

Andini, D. (2014). Potential of Katuk Leaf (Sauropus androgynus L. Merr) as aphrodisiac. Jurnal Majority, 3(7).

AOAC. 2005. Method of Analysis. 
Washington: Assosiation of Official Analytical Chemistry.

Ariesta, M. (2016). Variasi jenis bahan pengikat dan konsentrasi gliserol sebagai plasticizer pada pembuatan vegetable leather daun katuk (Sauropus androgynous) (Doctoral dissertation, Fakultas Teknik Unpas).

Basu, S., \& Shivhare, U. S. (2010). Rheological, textural, micro-structural and sensory properties of mango jam. Journal of Food Engineering, 100(2), 357-365.

del Castillo, M. L. R., RodríguezValenciano, M., Flores, G., \& Blanch, G. P. (2019). New method based on Solid Phase Microextraction and Multidimensional gas chromatographymass spectrometry to determine pesticides in strawberry jam. $L W T, 99$, 283-290.

Eng Khoo, H., Azlan, A., \& Ismaila, A. (2015). Sauropus androgynus leaves for health benefits: Hype and the science. The Natural Products Journal, 5(2), 115-123.

Feng, F., Li, M., Ma, F., \& Cheng, L. (2014). Effects of location within the tree canopy on carbohydrates, organic acids, amino acids and phenolic compounds in the fruit peel and flesh from three apple (Malus domestica) cultivars. Horticulture Research, 1(1), $1-7$.

Hardjanti, S. (2008). Potensi daun katuk sebagai sumber zat pewarna alami dan stabilitasnya selama pengeringan bubuk dengan menggunakan binder maltodekstrin. Jurnal Penelitian Saintek, 13(1).

Herianto, A., Hamzah, F., \& Yusmarini, Y. (2015). Studi pemanfaatan buah pisang mas (Musa acuminata) dan buah naga merah (Hylocereus Polyrhizus) dalam pembuatan selai. Jurnal Online Mahasiswa Fakultas Pertanian Universitas Riau, 2(2), 1-11.

Iswara, D. (2017). Pengaruh proporsi apel anna dan bunga rosella terhadap sifat fisikokimia dan organoleptik selai lembaran apel anna-rosella (Doctoral dissertation, Widya Mandala Catholic University Surabaya).

Khurniyati, M. (2014). Pengaruh konsentrasi natrium benzoat dan kondisi pasteurisasi (suhu dan waktu) terhadap karakteristik minuman sari apel dengan berbagai varietas. $[\mathrm{PhD}$ Thesis]. Universitas Brawijaya.

Lumbangaol, M. A., Nainggolan, R. J., \& Yusraini, E. (2016). The effect of ratio of pineapple juice with katuk leaf juice and carrageenan concentration on the quality of jelly candy. Jurnal Rekayasa Pangan dan Pertanian, 4(4), 492-499.

Mathebula, M. W., Mandiwana, K., \& Panichev, N. (2017). Speciation of chromium in bread and breakfast cereals. Food Chemistry, 217, 655659.

Nilasari, O. W., Susanto, W. H., \& Maligan, J. M. (2017). Pengaruh suhu dan lama pemasakan terhadap karakteristik lempok labu kuning (waluh). Jurnal Pangan dan Agroindustri, 5(3).

Oktaviananta, Y. S. (2018). Ekstraksi pigmen kulit apel anna (Mallus domestica) sebagai pigmen alami pada jelly drink apel dengan penambahan konsentrasi pigmen dan karagenan (Doctoral dissertation, University of Muhammadiyah Malang).

Putri, I. R., Basito, B., \& Widowati, E. (2013). Pengaruh konsentrasi agar-agar dan karagenan terhadap karakteristik fisik, kimia, dan sensori selai lembaran pisang (Musa paradisiaca L.) varietas raja bulu. Jurnal Teknosains Pangan, 2(3).

Rahmawati, A. A. (2016). Pengaruh perbandingan penambahan daun katuk dan lama pengeringan terhadap karakteristik fruit nori pisang (Musa paradisiaca formatypica) (Doctoral dissertation, Fakultas Teknik Unpas).

Santoso, U., Suteky, T., \& Fenita, Y. (2010). Effects of supplementation of alkaloid and non alkaloid from Sauropus androgynus leaves on egg production and lipid profil in layer chicken. 
Animal Production, 12(3).

Santoso, Urip, Lee, M. C., \& Nan, F. H. (2013). Effects of dietary katuk leaf extract on growth performance, feeding behavior and water quality of grouper Epinephelus coioides. Aceh International Journal of Science and Technology, 2(1), 17-25.

Satyaningtyas, E., \& Estiasih, T. (2013). Roti tawar laktogenik, perangsang ASI, berbasis kearifan lokal daun katuk (Sauropus androgynus (L.) Merr)[in press Januari 2014]. Jurnal Pangan dan Agroindustri, 2(1), 121-131.

Selvi, V. S., \& Bhaskar, A. (2012). Characterization of anti-inflammatory activities and antinociceptive effects of papaverine from Sauropus androgynus (L.) Merr. Glob J Pharmacol, 6(3), 186-92.

Violeta, N., Trandafir, I., \& Ionica, M. E. (2010). Compositional characteristics of fruits of several apple (Malus domestica Borkh.) cultivars. Notulae Botanicae Horti Agrobotanici ClujNapoca, 38(3), 228-233.

Wei, L. S., Wendy, W. E. E., Siong, J. Y. F., \& Syamsumir, D. F. (2011). Characterization of antimicrobial, antioxidant, anticancer properties and chemical composition of Sauropus androgynus stem extract. Acta Medica Lituanica, 18(1).

Zuhra, C. F., Tarigan, J. B., \& Sihotang, H. (2008). Aktivitas antioksidan senyawa flavonoid dari daun katuk (Sauropus androgunus (L) Merr.). Aktivitas antioksidan senyawa flavonoid dari daun katuk (Sauropus Androgunus (L) Merr.).Jurnal Biologi Sumatera, 3(1), 7-10. 